\title{
A phosphate-starvation-inducible outer- membrane protein of Pseudomonas fluorescens Ag1 as an immunological phosphate-starvation marker
}

\author{
Kristine Leopold, ${ }^{1}$ Susanne Jacobsen ${ }^{2}$ and Ole Nybroe ${ }^{1}$ \\ Author for correspondence: Ole Nybroe. Tel: +453528 2629. Fax: +453528 2606. \\ e-mail: Ole.Nybroe@ecol.kvl.dk
}

\footnotetext{
Section of Genetics and Microbiology, Department of Ecology and Molecular Biology, The Royal Veterinary and Agricultural University, Thorvaldsensvej 40 , DK1871 Frederiksberg C, Denmark

2 Department of Biochemistry and Nutrition, Building 224, The Technical University of Denmark, DK-2800 Lyngby, Denmark
}

\begin{abstract}
A phosphate-starvation-inducible outer-membrane protein of Pseudomonas fluorescens Ag1, expressed at phosphate concentrations below 0.08-0.13 mM, was purified and characterized. The purification method involved separation of outer-membrane proteins by SDS-PAGE and extraction of the protein from nitrocellulose or PVDF membranes after electrotransfer of proteins to the membranes. The $\mathbf{N}$-terminal amino acid sequence of the purified protein, called Psi1, did not show homology to any known proteins, and in contrast to the phosphate-specific porin OprP of $P$. aeruginosa its mobility in SDS-PAGE was not affected by solubilization temperature. An antiserum against Psi1 recognized a protein of $M_{r} 55000$ in four other $P$. fluorescens strains among 24 tested strains representing Pseudomonas rRNA homology group $I$, showing antigenic heterogeneity within this group. A method for immunofluorescence microscopy involving cell permeabilization was adapted to visualize cellspecific expression of Psi1 in P. fluorescens exposed to limiting amounts of phosphate. This approach should be useful for further exploration of Psi1 as a marker to study the availability of phosphate to $P$. fluorescens in natural environments.
\end{abstract}

Keywords: phosphate-starvation protein, Pseudomonas fluorescens, immunochemical single-cell detection

\section{INTRODUCTION}

The fluorescent pseudomonads are a group of bacteria which have received special attention due to the possible biotechnological exploitation of strains that promote plant growth (Keel et al., 1990; Höfte et al., 1991; Mazzola \& Cook, 1991) and of strains able to degrade xenobiotic compounds (Ramos et al., 1994). The utility of beneficial Pseudomonas strains requires successful colonization of natural environments but knowledge about the availability of substrates and nutrients in these habitats is scarce. For example, phosphorus is probably

Abbreviations: DAPI, 4',6-diamidino-2-phenylindoline; DMM, Davis minimal medium; DMM-P, Davis minimal medium depleted of phosphate; NCBI, National Center for Biotechnology Information; OM, outer membrane; Psi1, phosphate-starvation-inducible protein 1.

The PIR data library accession number for the sequence reported in this paper is P80694. not easily available to micro-organisms in the soil (Jungk et al., 1993; De Weger et al., 1994). As lack of phosphate severely reduces survival of pseudomonads in monoculture starvation experiments (Kragelund \& Nybroe, 1994; Eberl et al., 1996) phosphate limitation may represent a real and severe stress in natural environments.

When fluorescent pseudomonads encounter phosphate limitation they express a set of phosphate-starvation genes (Givskov et al., 1994; Kragelund et al., 1995). Lack of phosphate in complex, natural environments might therefore be monitored by reporter systems for gene expression rather than by chemical analyses that provide little information on the bioavailability of phosphate. Hence, transcriptional fusions between phosphate-regulated promoters and lacZ (De Weger et al., 1994) or lux $A B$ (Kragelund \& Nybroe, 1995) have been used to determine phosphate availability in plant-soil ecosystems. However, lacZ-tagged cells typically cannot be 
identified reliably at the single-cell level and furthermore a background of $\beta$-galactosidase activity may be present in the environment. In parallel, expression of bioluminescence from lux-tagged cells requires active metabolism and a sensitive charge-coupled device camera is needed for single-cell detection. Alternatively, the use of a starvation protein as an immunological marker allows detection of single cells by immunofluorescence microscopy provided that the selected marker is abundantly expressed. In addition, an immunological marker system can target cells which have not been genetically modified by insertion of a reporter gene.

The fluorescent pseudomonad Pseudomonas aeruginosa expresses abundant outer-membrane proteins as a response to phosphate limitation: the phosphate-specific porin OprP (Hancock et al., 1982) and the polyphosphate-specific porin OprO (Hancock et al., 1992). Phosphate-starvation-induced outer-membrane proteins have also been observed in some, but not all, $P$. fluorescens strains investigated (Poole \& Hancock, 1986; Poole et al., 1987; Kragelund \& Nybroe, 1994) and these outer-membrane proteins represent potential immunological markers. The purpose of this work was to develop an immunological marker system for phosphate-starved $P$. fluorescens. We have purified a phosphate-starvation-induced outer-membrane protein of $P$. fluorescens strain Ag1 and characterized the protein by amino acid analysis and $\mathrm{N}$-terminal amino acid sequence analysis. An antibody against the phosphatestarvation-induced protein has been raised and used to detect individual cells of $P$. fluorescens depleted of phosphate. The perspective of this approach is to use the antibody to study the availability of phosphate for pseudomonads in both simple systems and complex natural environments.

\section{METHODS}

Bacterial strains and culture media. Pseudomonas fluorescens strain Ag1 was originally isolated from soil. Specificity of the antibody produced during this study was tested against a panel of environmental $P$. fluorescens and P. putida strains and against type strains of rRNA homology group I pseudomonads (Table 1). Under non-starved conditions, the bacteria were grown aerobically at room temperature $\left(23-25^{\circ} \mathrm{C}\right)$ in Davis minimal medium, $\mathrm{pH} 7 \cdot 3$ [DMM; $0.4 \%$ glucose, $30 \mathrm{mM} \mathrm{K}_{2} \mathrm{HPO}_{4}, 14 \mathrm{mM} \mathrm{KH}_{2} \mathrm{PO}_{4}, 0.4 \mathrm{mM} \mathrm{MgSO}_{4}, 7.6 \mathrm{mM}$ $\left(\mathrm{NH}_{4}\right)_{2} \mathrm{SO}_{4}, 1.7 \mathrm{mM}$ sodium citrate supplemented with $1 \mathrm{ml}$ trace element solution $\mathrm{1}^{-1}$ ]. The trace element solution contained $20 \mathrm{mg} \mathrm{CoCl} .6 \mathrm{H}_{2} \mathrm{O}, \quad 30 \mathrm{mg} \mathrm{H} \mathrm{BO}_{3}, \quad 10 \mathrm{mg}$ $\mathrm{ZnSO}_{4} .7 \mathrm{H}_{2} \mathrm{O}, 1 \mathrm{mg} \mathrm{CuCl}{ }_{2} \cdot 2 \mathrm{H}_{2} \mathrm{O}, 2 \mathrm{mg} \mathrm{NiCl} \mathrm{m}_{2} \cdot 6 \mathrm{H}_{2} \mathrm{O}, 3 \mathrm{mg}$ $\mathrm{NaMoO}_{4} \cdot 2 \mathrm{H}_{2} \mathrm{O}, \quad 10 \mathrm{mg} \mathrm{FeSO}{ }_{4} \cdot 7 \mathrm{H}_{2} \mathrm{O}$, and $2.6 \mathrm{mg}$ $\mathrm{MnSO}_{4} \cdot \mathrm{H}_{2} \mathrm{O}$ dissolved in $1 \mathrm{l}$ demineralized water.

Phosphate starvation. Prior to starvation experiments, cells were grown overnight aerobically in DMM. The overnight culture was diluted to an $\mathrm{OD}_{600}$ of $0 \cdot 1$ as measured by a Perkin Elmer Lambda Bio Spectrometer with a $1 \mathrm{~cm}$ light path. When the cultures were again growing exponentially $\left(\mathrm{OD}_{600} 0 \cdot 4-0 \cdot 6\right)$, the cells were harvested by centrifugation at $6000 \mathrm{~g}$ for $10 \mathrm{~min}$ at room temperature, and washed twice with DMM without phosphate but supplemented with $10 \mathrm{mM}$ HEPES, $\mathrm{pH} 7 \cdot 3$, to maintain the $\mathrm{pH}(\mathrm{DMM}-\mathrm{P})$. The cells were then resuspended at the original cell density in DMM-P. After $15-25 \mathrm{~h}$, the cells were harvested by centrifugation at $6000 \mathrm{~g}$ for $10 \mathrm{~min}$.

Induction studies. P. fluorescens Ag1 was grown overnight aerobically in DMM supplemented with $0.8 \% \mathrm{KNO}_{3}$ and $0.2 \%$ Casamino acids (Difco) to reduce cell aggregation. A series of cultures with an $\mathrm{OD}_{600}$ of $0 \cdot 1$ was prepared by diluting the overnight culture. When the cultures were again growing exponentially $\left(\mathrm{OD}_{600} 0 \cdot 4-0.6\right)$, the cells were harvested by centrifugation at $6000 \mathrm{~g}$ for $10 \mathrm{~min}$, washed twice with DMM-P supplemented with $0 \cdot 04,0 \cdot 08,0 \cdot 13,0 \cdot 17,0 \cdot 22$, $0.25,0.30,0.35,0.40,0.45$ or $0.50 \mathrm{mM}$ inorganic phosphate, and resuspended in the respective medium at an $\mathrm{OD}_{600}$ of $0 \cdot 1$. After incubation for $2 \mathrm{~h} 20 \mathrm{~min}$ the protein synthesis was stopped by adding 200 p.p.m. chloramphenicol. Cells were harvested by centrifugation at $10000 \mathrm{~g}$ for $10 \mathrm{~min}$ at $4{ }^{\circ} \mathrm{C}$. The cell pellets were analysed by immunoblotting (see below).

The concentrations of inorganic phosphate in the supernatant at the beginning and at the end of the experiment were determined colorimetrically by a modified method of Heinonen \& Lahti (1981). Reaction solution (1 ml) containing 1 vol. $10 \mathrm{mM}\left(\mathrm{NH}_{4}\right)_{6} \mathrm{Mo}_{7} \mathrm{O}_{24} \cdot 4 \mathrm{H}_{2} \mathrm{O}, 1$ vol. $2 \cdot 5 \mathrm{mM} \mathrm{H}_{2} \mathrm{SO}_{4}$, and 2 vols acetone, was added to $200 \mu \mathrm{l}$ sample (containing 2.5-200 nmol phosphate). $A_{340}$ was measured.

SDSPAGE. Protein composition was analysed by SDS-PAGE and silver staining (Blum et al., 1987). SDS-PAGE was performed in $10 \%(\mathrm{w} / \mathrm{v})$ acrylamide and $0.27 \%(\mathrm{w} / \mathrm{v}) \mathrm{N}, \mathrm{N}^{\prime}$ methylenebisacrylamide separation gels overlaid with $4.5 \%$ acrylamide $/ 0 \cdot 12 \%$ methylenebisacrylamide stacking gels. Samples were, if not otherwise stated, solubilized by boiling for $5 \mathrm{~min}$ in sample buffer $(62.5 \mathrm{mM}$ Tris $/ \mathrm{HCl}, \mathrm{pH} 6.8$, containing $2.0 \%$ SDS, $6.25 \%$ glycerol, $0.005 \%$ bromphenol blue) including $0.47 \%$ DTT (reduced samples) or without DTT (non-reduced samples).

Cell fractionation. The procedure for cell fractionation was modified from Yamamoto et al. (1987). Phosphate-starved cells of $P$. fluorescens $\mathrm{Ag} 1$ were harvested by centrifugation at $7000 \mathrm{~g}$ for $10 \mathrm{~min}$ at room temperature. The supernatant, representing the culture medium, was filtered through $0.2 \mu \mathrm{m}$ pore-size polycarbonate filters (Nuclepore). The cells were subsequently washed and incubated for $10 \mathrm{~min}$ at room

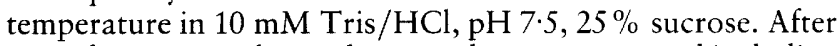
centrifugation as above, the procedure was repeated including $1 \mathrm{mM}$ EDTA in the buffer. The supernatants, representing extracellular material, were collected. The cells were then resuspended in ice-cold water and shaken vigorously for $10 \mathrm{~min}$ on ice. Following centrifugation at $9000 \mathrm{~g}$ for $10 \mathrm{~min}$ at $4{ }^{\circ} \mathrm{C}$ the supernatant, representing the periplasmic fraction, was removed. The cell pellet was resuspended in $10 \mathrm{mM}$ Tris $/ \mathrm{HCl}$ and sonicated for $2 \mathrm{~min}$ on ice using an MSE $150 \mathrm{~W}$ Ultrasonic disintegrator (Sanoy), probe diameter $9.5 \mathrm{~mm}$, at $10 \mu \mathrm{m}$ amplitude. Remaining whole cells were removed by centrifugation at $9000 \mathrm{~g}$ for $10 \mathrm{~min}$ and cell walls were subsequently pelleted by centrifugation at $47000 \mathrm{~g}$ for $2 \mathrm{~h}$ at $4{ }^{\circ} \mathrm{C}$. The new supernatant represented the cytoplasmic fraction. Half of the pellet was immediately frozen (cell wall fraction) while the remaining half was used to prepare outer membranes (see below).

Protein concentrations were, throughout this work, determined by the bicinchoninic acid protein assay (Pierce) using BSA as a standard.

Preparation of outer membranes. Outer membranes were isolated by the Sarkosyl method (Filip et al., 1973), essentially as described by Kragelund \& Nybroe (1994). However, when 
Table 1. Specificity of the antibody raised against Psi1 of $P$. fluorescens Ag1 tested by immunoblotting analysis of strains from the genus Pseudomonas and of Escherichia coli

Each sample contained approximately $10^{7}$ cells; all samples were non-reduced.

\begin{tabular}{|c|c|c|c|}
\hline \multirow[t]{2}{*}{ Strain } & \multirow[t]{2}{*}{ Biovar } & \multicolumn{2}{|c|}{$\begin{array}{l}\text { Strength of reaction }{ }^{*} \text { of antibody with } \\
\text { protein from cells which were: }\end{array}$} \\
\hline & & $\begin{array}{l}\text { Solubilized at } \\
100^{\circ} \mathrm{C} \text { prior } \\
\text { to electrophoresis }\end{array}$ & $\begin{array}{c}\text { Solubilized at room } \\
\text { temperature prior } \\
\text { to electrophoresis }\end{array}$ \\
\hline P. fluorescens Ag1 & II & $+++(55)$ & $\begin{array}{c}+(55) \\
++(70-110)\end{array}$ \\
\hline P. fluorescens ON24† & I & - & - \\
\hline P. fluorescens MM5† & I & - & - \\
\hline P. fluorescens MM6† & II & - & - \\
\hline P. fluorescens DF8† & II & - & - \\
\hline P. fluorescens DF57† & II & - & - \\
\hline P. fluorescens DF61† & III & - & - \\
\hline P. fluorescens DF23† & IV & - & - \\
\hline P. fluorescens DF18† & IV & - & - \\
\hline P. fluorescens ON13† & $\mathrm{V}$ & $++(55)$ & $+(55)$ \\
\hline P. fluorescens ON25† & $\mathrm{V}$ & $++(55)$ & $++(55)$ \\
\hline P. fluorescens DF17† & $\mathrm{V}$ or $\mathrm{VI} \neq$ & - & - \\
\hline P. fluorescens ON5† & V or VI $\neq$ & - & - \\
\hline P. fluorescens DSM $50090^{\mathrm{T}}$ & I & - & - \\
\hline P. fluorescens DSM 50106 & II & $+++\langle 55\rangle$ & $+++(55)$ \\
\hline P. fluorescens DSM 50124 & III & - & - \\
\hline P. fluorescens DSM 50415 & IV & - & - \\
\hline P. fluorescens DSM 50148 & $\mathrm{~V}$ & $+++(55)$ & $+(55)$ \\
\hline P. putida DSM $291^{\mathrm{T}}$ & A & - & - \\
\hline P. putida DSM 50222 & B & - & - \\
\hline P. stutzeri DSM $5190^{\mathrm{T}}$ & - & - & - \\
\hline P. aeruginosa DSM $50071^{\mathrm{T}}$ & - & - & - \\
\hline P. chlororaphis DSM $50083^{\mathrm{T}}$ & - & - & - \\
\hline P. syringae ATCC $19310^{\mathrm{T}}$ & - & - & - \\
\hline E. coli DSM 498 & - & - & - \\
\hline
\end{tabular}

$*+++$, Strong reaction; ++ , medium reaction; + , weak reaction; - , no reaction. Figures in parentheses are $10^{-3} \times M_{\mathrm{r}}$ of the reactive protein.

† Classified by the API 20NE system supplemented by additional tests (Sørensen et al., 1992).

$\ddagger$ New biotype VI according to Barrett et al. (1982).

outer membranes were prepared from whole phosphatestarved cells, sonication with an MSE 150W Ultrasonic Disintegrator (settings as above) for $10 \times 2$ min on ice was required to rupture cells. The membrane preparations were stored at $-20^{\circ} \mathrm{C}$ after addition of $100 \mathrm{U}$ aprotinin $\mathrm{ml}^{-1}$ (Sigma).

Purification of protein from nitrocellulose membranes. Outer-membrane proteins of phosphate-starved P. fluorescens Ag1 were separated by SDS-PAGE under non-reducing conditions as described above. Proteins were transferred to nitrocellulose membranes (Schleicher \& Schuell BA85, $0.45 \mu \mathrm{m}$ ) by semi-dry electroblotting (Kem-En-Tec) at $0.8 \mathrm{~mA} \mathrm{~cm}^{-2}$ for $2 \mathrm{~h}$. To purify the protein of interest, its position on the nitrocellulose membrane was identified by staining part of the membrane with $0.2 \%$ Ponceau $S$ in $5 \%$ acetic acid (Sigma). The protein was cut out from the unstained part of the nitrocellulose membrane using the stained part as a template and purified by elution with formic acid (Judd, 1988). Purity of the eluted protein was monitored by SDS-PAGE and protein-specific silver staining (Blum et al., 1987) or lipopolysaccharide-specific periodate/silver staining (Tsai \& Frasch, 1982). The preparation was kept at $-20^{\circ} \mathrm{C}$ if not used immediately.

Amino acid analysis and $\mathrm{N}$-terminal amino acid sequence analysis. Outer membranes were subjected to SDS-PAGE as above followed by electroblotting onto a PVDF membrane (Bio-Rad) (Matsudaira, 1987). The protein of interest was localized by staining with Coomassie R250 (Merck) and cut out. The stained band was thoroughly washed in demineralized water, dried under nitrogen and used for amino acid analysis and $\mathrm{N}$-terminal amino acid sequencing. The protein was hydrolysed at $110^{\circ} \mathrm{C}$ in $6 \mathrm{M} \mathrm{HCl}, 0.05 \%$ phenol and $5 \mu \mathrm{l}$ $1 \% 3,3^{\prime}$-dithiodipropionic acid for $24 \mathrm{~h}$ and $72 \mathrm{~h}$ (Barkholt $\&$ Jensen, 1989). Cysteine/cystine was derivatized with 3,3'- 
dithiodipropionic acid during hydrolysis. Amino acids were determined by cation-exchange chromatography and postcolumn derivatization with $o$-phthaldialdehyde. N-terminal amino acid sequence analysis of PVDF-bound protein was carried out by automated Edman degradation using an Applied Biosystems Procise 494 sequencer as described by the manufacturer. Multiple alignments of protein sequences and nucleotide sequences were performed using the BLAST network service at the National Center for Biotechnology Information.

Production of antiserum. Antiserum against purified protein was made by immunizing two mice (strain Ssc:CF1) subcutaneously each with approximately $5 \mu \mathrm{g}$ purified protein mixed $(1: 1)$ with Freund's incomplete adjuvant (State Serum Institute, Denmark) four times at 2 week intervals. Immunization was done by the State Serum Institute, Denmark. Two weeks after the fourth immunization the mice were killed and blood was collected. Serum was obtained by centrifugation and $\mathrm{NaN}_{3}(15 \mathrm{mM})$ was added as a preservative.

Immunoblotting. SDS-PAGE and electrotransfer of protein to nitrocellulose membranes were as described above. After electrotransfer, the blot was blocked for $20 \mathrm{~min}$ in $50 \mathrm{mM}$ Tris/HCl, pH 10.2, $150 \mathrm{mM} \mathrm{NaCl}, 2 \%$ Tween 20, 0.5\% BSA, $1 \%$ casein. After blocking the nitrocellulose membrane was incubated overnight at room temperature with antiserum. The antiserum specific to the phosphate-starvation protein was diluted 1:30000 and antiserum against OprF (Kragelund et al., 1996) was diluted $1: 17500$ with $50 \mathrm{mM}$ Tris $/ \mathrm{HCl}$, pH $10 \cdot 2,150 \mathrm{mM} \mathrm{NaCl}, 0.05 \%$ Tween $20,0 \cdot 5 \%$ BSA, $0.3 \%$ casein. After washing three times in washing buffer $(50 \mathrm{mM}$ Tris/ $\mathrm{HCl}, \mathrm{pH} 10 \cdot 2,150 \mathrm{mM} \mathrm{NaCl}, 0.05 \%$ Tween $20,0.05 \%$ $\mathrm{BSA}$, the nitrocellulose membrane was incubated for $2 \mathrm{~h}$ with alkaline-phosphatase-conjugated rabbit anti-mouse immunoglobulins (1:1000 in dilution buffer) (DAKO). After three washes, colour was developed with $0 \cdot 1 \mathrm{mg}$ nitroblue tetrazolium $\mathrm{ml}^{-1}$ (Sigma), $0.06 \mathrm{mg} 5$-bromo-4-chloro-3-indolyl phosphate $\mathrm{ml}^{-1}$ (Sigma), $20 \mathrm{mM} \mathrm{MgCl}_{2}$ in $100 \mathrm{mM}$ ethanolamine, pH 9.6.

Dot-immunoblotting. Samples were collected on a nitrocellulose membrane by filtration. The membrane was immunostained essentially as described for immunoblotting. However incubation with PBS $(25 \mathrm{mM}$ sodium phosphate, $\mathrm{pH} 7 \cdot 4$, $125 \mathrm{mM} \mathrm{NaCl}$ ) adjusted to $\mathrm{pH} 2.8$ was included to inhibit indigenous alkaline phosphatase activity (Olsen \& Rice, 1989). The filters were treated with $100 \mathrm{mM}$ Tris $/ \mathrm{HCl}, \mathrm{pH} 7 \cdot 5$, $50 \mathrm{mM}$ sodium metaperiodate for $3 \times 20 \mathrm{~min}$ at room temperature before incubation with antibodies.

Immunofluorescence microscopy. The procedure for immunofluorescence microscopy was modified from Maddock \& Shapiro (1993) and Harry et al. (1995). After vortexing to disperse cell aggregates, cells were fixed by adding buffered formaldehyde to a final concentration of $2 \%$, and kept on ice for $1 \mathrm{~h}$ and at room temperature for at least $3 \mathrm{~h}$. All subsequent steps were performed at room temperature if not otherwise stated. Fixed cells were washed three times in PBS, submitted to oxidation of carbohydrates by $1 \%$ sodium metaperiodate for $15 \mathrm{~min}$, washed once in PBS and quenched for $15 \mathrm{~min}$ in $50 \mathrm{mM} \mathrm{NH}_{4} \mathrm{Cl}$. Following a final wash in demineralized water, samples of $50 \mu \mathrm{l}$ were transferred to poly-L-lysinecoated slides. After $30 \mathrm{~s}$ the liquid was removed and the slides allowed to dry. The cells were then permeabilized by transfer to $-20^{\circ} \mathrm{C}$ methanol for $5 \mathrm{~min}$ and $-20^{\circ} \mathrm{C}$ acetone for $30 \mathrm{~s}$ and again allowed to dry. The slides were immunostained as described for immunoblotting, with the following modifications: all buffers were at $\mathrm{pH} 7 \cdot 6$, the phosphate starvation protein antiserum was diluted $1: 100$, and the secondary antibody was fluorescein-conjugated goat anti-mouse immunoglobulin (DAKO) diluted 1:20.

\section{RESULTS}

\section{Purification of Psi1}

Outer-membrane preparations from exponentially growing and from phosphate-starved P. fluorescens Ag1 were analysed by SDS-PAGE. A protein of $M_{\mathrm{r}} 55000$, which we called phosphate-starvation-inducible protein 1 (Psi1), appeared under phosphate starvation (Fig. 1, compare lanes 1 and 2) but not under either carbon or nitrogen starvation (data not shown). When reduced, Psi1 appeared to have a slightly higher $M_{\mathrm{r}}$, approximately 56000, than non-reduced Psi1 (Fig. 1, lanes 2 and 4). When outer-membrane samples were solubilized in sample buffer at room temperature instead of at $100^{\circ} \mathrm{C}$, the mobility of the Psil protein was unaltered, but the Psi1 protein band was less intense.

The $M_{\mathrm{r}} 55000$ form of Psi1 was purified from outer membranes by elution from nitrocellulose membranes after electrotransfer from SDS-polyacrylamide gels. The protein preparation obtained was electrophoretically pure as demonstrated by SDS-PAGE and protein-specific silver staining (Fig. 2, lane 3). No lipopolysaccharide could be detected by carbohydrate-specific periodate/ silver staining (data not shown). The purified Psi1 protein migrated at $M_{\mathrm{r}} 56000$, whether heated or not prior to electrophoresis (Fig. 2, lanes 3 and 4). The $M_{\mathrm{r}} 56000$ form probably represents fully denatured protein obtained either by treatment with SDS plus reducing agent or by the acid treatment included in the purification procedure. The recovery of Psi1 was approximately $40 \mu \mathrm{g}$ per $1000 \mu \mathrm{g}$ outer-membrane-protein prep-

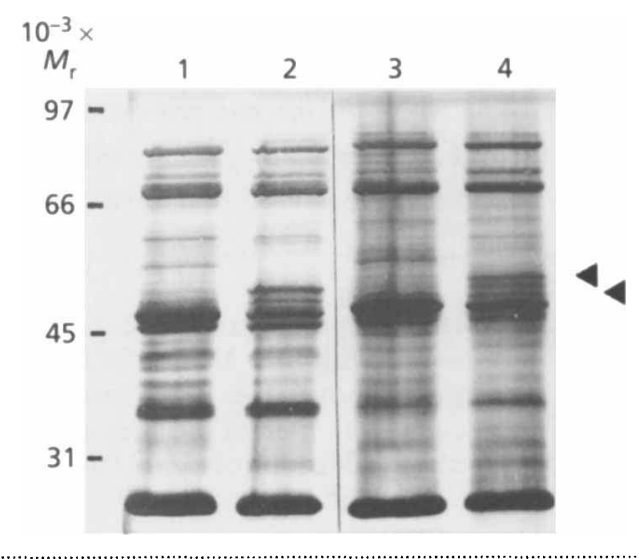

Fig. 1. SDS-PAGE of outer-membrane proteins of $P$. fluorescens $\mathrm{Ag} 1$ starved of phosphate. Lanes with odd numbers, outer membranes from exponential phase cells; lanes with even numbers, outer membranes from phosphate-starved cells. Samples in lanes 1 and 2 are non-reduced and samples in lanes 3 and 4 are reduced. All samples were solubilized in sample buffer at $100^{\circ} \mathrm{C}$ for $5 \mathrm{~min}$ prior to electrophoresis. Gels are silver stained. The $M_{\mathrm{r}} 55000$ and the 56000 forms of Psi1 are marked by arrows. The migration positions of $M_{r}$ standards are indicated. 


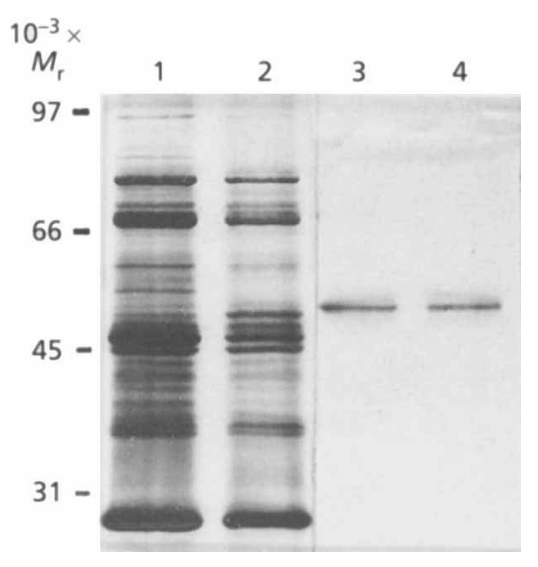

Fig. 2. SDS-PAGE of purified Psi1 protein. Lane 1, outer membranes from exponential phase $P$. fluorescens Ag1 cells; lane 2, outer membranes from phosphate-starved $P$. fluorescens Ag1 cells; lane 3 , purified Psi1, solubilized at $100^{\circ} \mathrm{C}$ prior to electrophoresis; lane 4, purified Psi1, solubilized at room temperature prior to electrophoresis. All samples are nonreduced. Gels are silver stained. The migration positions of $M_{\mathrm{r}}$ standards are indicated.

aration, indicating that it is a major component of the outer membrane of starving cells.

\section{Amino acid composition and $\mathrm{N}$-terminal amino acid sequence analysis}

To determine whether Psi1 was related to other known outer-membrane proteins, amino acid analysis and $\mathrm{N}$ terminal amino acid sequence analysis of Psi1 were performed. The analyses were done on PVFDmembrane-bound purified protein. The amino acid composition of Psi1 is listed in Table 2 along with the previously published amino acid compositions of the phosphate-starvation-induced outer-membrane porins OprP of P. aeruginosa and PhoE of Escherichia coli and of the major outer-membrane protein OprF of $P$. fluorescens and $P$. aeruginosa. The overall amino acid composition appeared fairly similar between the compared proteins, containing $34-38 \%$ charged residues (Asp, Glu, His, Lys and Arg) and 31-38\% hydrophobic residues (Pro, Ala, Val, Met, Ile, Leu, Phe and Trp). The phosphate-starvation-induced proteins (Psi1, OprP and PhoE) showed lower contents of proline and valine than OprF. Psil furthermore differed from OprP in a higher Glu/GIn ratio and a lower Gly content. The sequence of the $39 \mathrm{~N}$-terminal amino acids of Psi1 was: AVDAKLLDMLKANGQISASQYTELQAELAKDQKEKQIAQ. A homology search was carried out with all available sequence databases but did not reveal any homology to known proteins.

\section{Specificity of the polyclonal antiserum raised against Psi1}

A polyclonal antiserum against purified Psi1 was raised in mice and the specificity of this antiserum was determined by immunoblot analysis of outer-membrane
Table 2. Amino acid composition of the phosphatestarvation-induced outer-membrane protein of P. fluorescens Ag1, Psi1, and amino acid composition of selected outer-membrane proteins of $P$. fluorescens, $P$. aeruginosa and $E$. coli

\begin{tabular}{|c|c|c|c|c|c|}
\hline \multirow{3}{*}{$\begin{array}{l}\text { Amino } \\
\text { acid }\end{array}$} & \multicolumn{5}{|c|}{ Composition ( $\mathrm{mol} \%)$} \\
\hline & \multicolumn{2}{|c|}{ P. fluorescens } & \multicolumn{2}{|c|}{ P. aeruginosa } & \multirow{2}{*}{$\begin{array}{l}\text { E. coli } \\
\text { PhoE }\end{array}$} \\
\hline & Psil* & OprF十 & OprPł & OprF\$ & \\
\hline Asp/Asn & $14 \cdot 5$ & $13 \cdot 2$ & $14 \cdot 8$ & $15 \cdot 3$ & $17 \cdot 6$ \\
\hline Thr & $6 \cdot 3$ & $4 \cdot 6$ & $6 \cdot 8$ & $5 \cdot 4$ & $7 \cdot 0$ \\
\hline Ser & $6 \cdot 7$ & $6 \cdot 3$ & $8 \cdot 3$ & $6 \cdot 4$ & $5 \cdot 4$ \\
\hline Glu/Gln & $11 \cdot 6$ & $9 \cdot 9$ & $8 \cdot 0$ & $10 \cdot 2$ & $9 \cdot 1$ \\
\hline Pro & $2 \cdot 0$ & $5 \cdot 3$ & 1.6 & $3 \cdot 1$ & $0 \cdot 9$ \\
\hline Gly & $11 \cdot 4$ & $10 \cdot 9$ & $14 \cdot 3$ & $11 \cdot 2$ & $10 \cdot 9$ \\
\hline Ala & $10 \cdot 0$ & $12 \cdot 3$ & $10 \cdot 4$ & $9 \cdot 5$ & $8 \cdot 1$ \\
\hline Cys & $0 \cdot 1$ & $0 \cdot 0$ & $0 \cdot 0$ & $1 \cdot 3$ & $0 \cdot 0$ \\
\hline Val & $4 \cdot 9$ & $9 \cdot 6$ & $5 \cdot 5$ & $8 \cdot 5$ & $3 \cdot 6$ \\
\hline Met & 0.9 & $0 \cdot 3$ & $1 \cdot 3$ & $1 \cdot 7$ & $2 \cdot 1$ \\
\hline Ile & $3 \cdot 9$ & $2 \cdot 0$ & $1 \cdot 8$ & $2 \cdot 4$ & $3 \cdot 9$ \\
\hline Leu & $8 \cdot 2$ & $5 \cdot 0$ & $6 \cdot 8$ & $4 \cdot 8$ & $6 \cdot 4$ \\
\hline Tyr & $4 \cdot 0$ & $5 \cdot 0$ & $5 \cdot 2$ & $5 \cdot 4$ & $6 \cdot 7$ \\
\hline Phe & $3 \cdot 6$ & $3 \cdot 3$ & $3 \cdot 6$ & $3 \cdot 7$ & $6 \cdot 4$ \\
\hline His & $1 \cdot 7$ & $2 \cdot 0$ & $0 \cdot 8$ & $1 \cdot 8$ & $0 \cdot 3$ \\
\hline Lys & $6 \cdot 3$ & $5 \cdot 0$ & $4 \cdot 9$ & $4 \cdot 3$ & $7 \cdot 0$ \\
\hline Arg & $4 \cdot 1$ & $5 \cdot 0$ & $5 \cdot 7$ & $4 \cdot 2$ & $3 \cdot 6$ \\
\hline Trp & ND & $0 \cdot 3$ & ND & 0.7 & $0 \cdot 9$ \\
\hline
\end{tabular}

ND, Not determined.

*Values were obtained after $24 \mathrm{~h}$ hydrolysis, except for Val and Ile $(72 \mathrm{~h}$ hydrolysis). Values for Thr and Ser were obtained by extrapolation to zero time of hydrolysis. Cys was determined as half-cystine.

$\dagger$ Derived from the nucleotide sequence of the protein (De Mot et al., 1994).

¥Amino acid analysis (Worebec et al., 1988). Values were obtained after $24 \mathrm{~h}$ hydrolysis.

$\$$ Amino acid analysis (Mizuno \& Kageyama, 1979). Means of values obtained at 24,48 , and $72 \mathrm{~h}$ hydrolysis. Values for Thr and Ser were obtained by extrapolation to zero time of hydrolysis. Cys was determined as half-cystine. The values for half-cystine and Met were obtained by amino acid analysis after performic acid oxidation of the samples.

$\|$ Derived from the nucleotide sequence of the protein (Overbeeke et al., 1983).

preparations from $P$. fluorescens Ag1. The antiserum recognized a protein of $M_{r} 55000$ in outer membranes from phosphate-starved cells, whereas no reaction with outer membranes from non-starved cells could be seen (Fig. 3, compare lanes 1 and 2). If the outer-membrane preparation was not heated prior to electrophoresis a smear of varying width, $M_{\mathrm{r}}$ approximately $70000-110000$, appeared in addition to the $M_{\mathrm{r}} 55000$ band (Fig. 3, lane 3). When tested against a number of $P$. fluorescens strains representing all biovars of this species and against a panel of type strains from RNA homology 


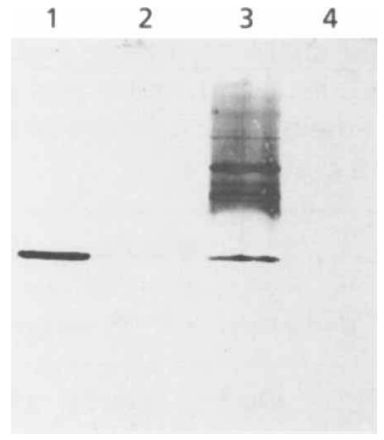

Fig. 3. Specificity of the polyclonal antiserum raised against Psil tested by immunoblotting. Lanes with odd numbers, outer membranes from phosphate-starved $P$. fluorescens $\mathrm{Ag} 1$; lanes with even numbers, outer membranes from exponential-phase $P$. fluorescens $\mathrm{Ag} 1$. Samples in lanes 1 and 2 were solubilized at $100^{\circ} \mathrm{C}$ prior to electrophoresis and samples in lanes 3 and 4 were solubiized at room temperature prior to electrophoresis. All samples are non-reduced.

(a)

(b)

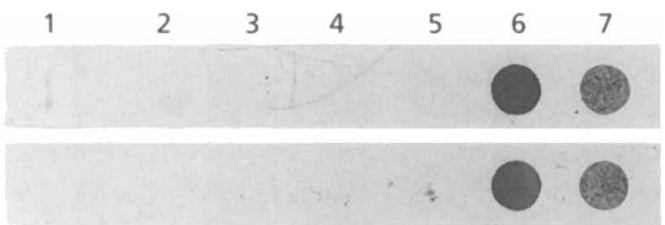

Fig. 4. Cellular localization of Psi1 of $P$. fluorescens demonstrated by dot immunobinding analysis of subcellular fractions. (a) Incubation with antibody against Psi1; (b) incubation with antibody against OprF. Dot 1, culture medium; dot 2, extracellular material released by Tris/sucrose buffer; dot 3, extracellular material released by Tris/sucrose/EDTA buffer; dot 4, periplasmic fraction; dot 5, cytoplasmic fraction; dot 6 , cell wall fraction; dot 7 , outer membrane fraction. Each dot contains $5 \mu \mathrm{g}$ total protein.

group I pseudomonads (Table 1) and Escherichia coli, the antiserum reacted with proteins with relative molecular masses of approximately 55000 in only the following strains of $P$. fluorescens: DSM 50106 (biovar II), DSM 50148 (biovar V), ON13 (biovar V) and ON25 (biovar V) (see Table 1), whether or not the cells were heated prior to electrophoresis.

\section{Cellular localization}

Cells of phosphate-starved P. fluorescens Ag1 were fractionated and the localization of Psi1 was determined by dot-immunobinding (Fig. 4). The localization of a well-known outer-membrane marker, OprF (Hancock et al., 1990), was determined as a control. Psi1 and OprF co-localized to cell wall and outer-membrane fractions. Neither of the proteins was found in extracellular material, in the periplasm or in the cytoplasm.

The antibody raised against Psil did not react with intact phosphate-starved Ag1 cells in immunofluorescence microscopy, suggesting either that the protein did not contain surface-exposed epitopes or that

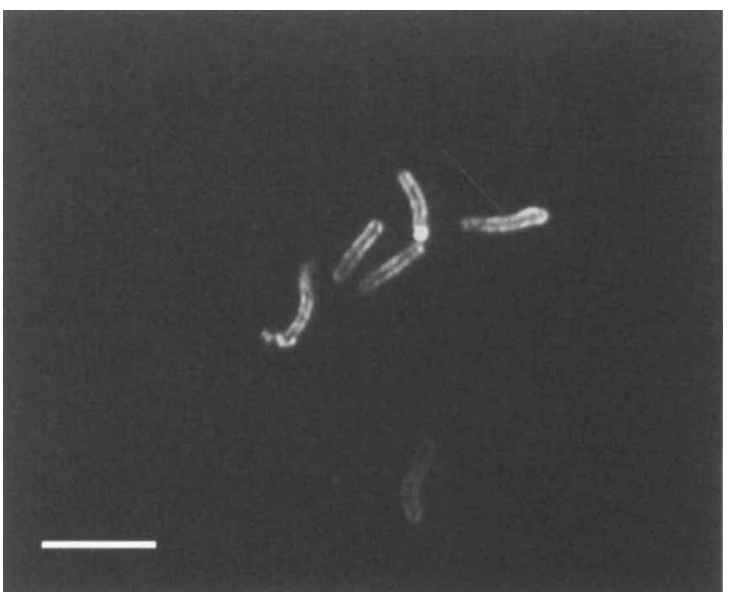

Fig. 5. Phosphate-starved $P$. fluorescens $\mathrm{Ag} 1$ detected by immunofluorescence microscopy using antiserum against Psi1 after fixation and permeabilization of cells. Bar, $5 \mu \mathrm{m}$.

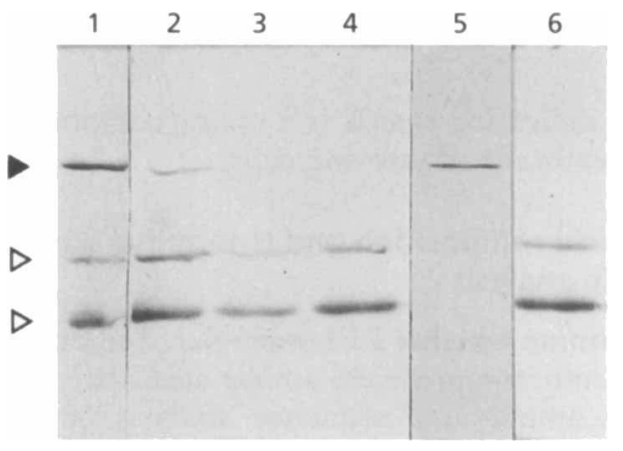

Fig. 6. Induction of Psi1 examined by immunoblotting. Cells were grown at the following phosphate concentrations: $0.04 \mathrm{mM}$ (lane 1), $0.08 \mathrm{mM}$ (lane 2), $0.13 \mathrm{mM}$ (lane 3), $0.17 \mathrm{mM}$ (lane 4). The blot was co-incubated with antiserum against Psi1 and antibody against OprF. Lanes 5 and 6 are controls and represent phosphate-starved cells incubated with anti Psi1 and anti OprF (appearing as two bands), respectively. The location of Psi1 is shown by a solid arrow and that of OprF by open arrows.

such epitopes were masked. However, a distinct surface staining of starved cells was apparent when the cells were fixed with formaldehyde, permeabilized with methanol/acetone and treated with metaperiodate to oxidize cell wall carbohydrates prior to immunostaining (Fig. 5). Treatment with lysozyme to disrupt cell wall carbohydrates was less efficient than metaperiodate oxidation (data not shown). Exponentially growing cells submitted to the above-mentioned procedure gave no signal (data not shown).

\section{Expression of Psi1 at different phosphate concentrations}

The lowest phosphate concentration resulting in expression of Psi1 was determined by incubating Ag 1 cells at phosphate concentrations ranging from 0 to $0.50 \mathrm{mM}$ 
and subsequently analysing the cells by immunoblotting to detect both Psi1 and the constitutive marker OprF. When cells were transferred to phosphate-free medium, Psi1 could be detected by immunoblotting after approximately $70 \mathrm{~min}$. To ensure detection of Psi1, induction studies were performed for $2 \mathrm{~h} 20 \mathrm{~min}$. During this period there was no detectable consumption of phosphate in the cultures. It was found that Psil was induced at phosphate concentrations between approximately 0.08 and $0.13 \mathrm{mM}$ (Fig. 6).

\section{DISCUSSION}

\section{Characterization of the phosphate-starvation- inducible protein Psi1}

Under conditions of phosphate limitation fluorescent pseudomonads express a set of starvation proteins. For example, at least 56 phosphate-starvation proteins are induced in P. putida strain KT2442 (Givskov et al., 1994), and in P. fluorescens strain DF57 induction of several phosphate-starvation genes has been reported (Kragelund et al., 1995). In the present work we describe a major phosphate-starvation-inducible protein, Psi1, from P. fluorescens strain Ag1. The Psi1 protein from strain Ag1 is induced during phosphate deprivation and is likely to be a member of the phosphate-starvation (Pho) regulon (Siehnel et al., 1990; Siehnel et al., 1992) but the protein is not a general starvation marker. Psi1 is induced at phosphate concentrations below $0.08-0.13 \mathrm{mM}$. This limit is close to the limit reported for the phosphate-induced protein OprP from $P$. aeruginosa (0.10-0.20 mM; Hancock et al., 1982) whereas De Weger et al. (1994) reported that a phosphateregulated lac $Z$ fusion in $P$. fluorescens strain WCS358 was induced when the phosphate concentration dropped below approximately $0.03 \mathrm{mM}$. This difference may be due to differences in experimental set-up: the threshold for the WCS358 gene fusion was determined while the cells were continuously depleting a medium rich in phosphate, while we used incubations in minimal medium at fixed phosphate concentrations. Finally, the sensitivity of the detection systems may differ.

Both cell fractionation experiments and immunocytochemical evidence demonstrate that the $M_{\mathrm{r}} 55000$ Psi1 protein is exclusively localized in the outer membrane. In $P$. aeruginosa, the $M_{\mathrm{r}} 48000$ phosphate-specific outermembrane porin $\mathrm{OprP}$ is induced during limitation for phosphate, and outer-membrane proteins with comparable properties have been demonstrated in at least one P. fluorescens strain (Poole \& Hancock. 1986; Poole et al., 1987). We therefore addressed the possibility that Psi1 could represent a P. fluorescens homologue to OprP. However, the amino acid compositions of Psi1 and OprP were distinctly different and $\mathrm{N}$-terminal amino acid sequence analysis of Psi1 did not reveal homology to any known sequences. By contrast, the Nterminal amino acid sequences of $\mathrm{OprF}$ of $P$. aeruginosa and $P$. fluorescens show high homology (Duchêne et al., 1988; De Mot et al., 1994) and the N-terminal amino acid sequences of many enterobacterial outer membrane proteins can be aligned with homology (Jeanteur et al., 1991).

The electrophoretic mobility and solubilization characteristics in SDS-PAGE differ between OprP and Psi1. The relative molecular mass of Psi1 in SDS-PAGE is 55000 after solubilization in SDS at $100^{\circ} \mathrm{C}$. The mobility of Psi1 is not affected by solubilization temperature in four out of five Pseudomonas strains expressing this protein. In $P$. fluorescens strain $\mathrm{Ag} 1$, however, the protein migrates in part as a smear of $M_{\mathrm{r}}$ approximately 70000-110000 if samples are solubilized at room temperature. This smear may be attributed to the association of the protein with other cell envelope components, such as exopolysaccharides, which this strain produces in copious amounts (Boye et al., 1995). OprP on the other hand is a trimer and is resistant to denaturation to monomers by SDS. It consequently appears as trimers of $M_{\mathrm{r}}$ approximately 97000 in SDSPAGE when not heated in SDS prior to electrophoresis, whereas the monomer, obtained by solubilization at $88^{\circ} \mathrm{C}$, migrates at $M_{\mathrm{r}} 48000$ (Poole et al., 1987). In conclusion, the above data on amino acid composition, amino acid sequence, electrophoretic mobility and solubilization properties suggest that Psi1 is not closely related to OprP. However, we cannot at this point exclude the possibility that OprP of $P$. aeruginosa and $P$. fluorescens display considerable $\mathrm{N}$-terminal heterogeneity, for example by the addition of an extra $\mathrm{N}$-terminal domain to the $P$. fluorescens protein. This could explain the observed differences in amino acid sequence and electrophoretic mobility between OprP and Psi1.

The antiserum raised against Psi1 from strain Ag1 crossreacts with only four other $P$. fluorescens strains among the 24 tested strains representing Pseudomonas rRNA homology group I and also does not react with phosphate-starvation-induced proteins from E. coli. Previously, Kragelund \& Nybroe (1994) reported that the number and mobility of phosphate-starvationinduced outer-membrane proteins varied considerably among $P$. fluorescens and $P$. putida strains. One of these strains, $P$. fluorescens DF57, expressed a $M_{\mathrm{r}} 55000$ protein which, however, did not react with Psi1 antibody. Taking into account that OprP-like molecules have been characterized in some P. fluorescens strains (Poole \& Hancock, 1986; Poole et al., 1987; Siehnel et al., 1990), the conclusion that can be drawn from the available data is that phosphate-starvation-induced outer-membrane proteins within $P$. fluorescens are heterogeneous.

\section{Immunological detection of individual phosphate- starved cells}

More information about the physiological responses of bacteria in natural habitats might be obtained by studying environmentally regulated gene expression under controlled laboratory conditions, and then developing systems which can allow us to detect expression of the selected genes under complex environmental conditions. Studies of bacterial physiology, such as during 
starvation, in pure culture experiments have already revealed a considerable physiological heterogeneity between individual cells (Schaule et al., 1993; Eberl et al., 1996), making it crucial to establish reporter systems which can monitor the expression of specific functions at the single-cell level.

In the present study, we have developed an efficient and reliable cell-specific reporter system for phosphate limitation based on immunological recognition of Psi1. Initial attempts to visualize Psi1 by immunofluorescence microscopy of intact cells were unsuccessful (data not shown). This could indicate that the protein is shielded by, for example, bulky lipopolysaccharide (LPS) or exopolysaccharide. The $\mathrm{O}$ antigen in LPS has been reported to shield outer-membrane proteins (van der Ley et al., 1986; Zaat et al., 1994). Treatment with EDTA, which has previously been used to unmask outer-membrane proteins in pseudomonads (Zaat et al., 1994; Kragelund et al., 1996), did not improve the detection of Psi1, indicating that surface-exposed epitopes were not targeted by the antibody. However, immunofluorescence microscopy of fixed, permeabilized cells yielded the required signal specific to phosphatestarved cells.

Immunological reporter systems provide a sensitive means of cell-specific detection. Hence, Zaat et al. (1994) developed a marker for phosphate starvation based on a PhoE-ColA hybrid protein. However this marker could only be detected in a mutant of $P$. putida strain WCS358 lacking LPS O side chains. More recently, toluene degradation by $P$. putida KT2442 was visualized by an immunological reporter system targeting LamB, presenting a corona virus epitope, under the control of a catabolic promoter (Cebolla et al., 1996). The present Psi1-targeted system is directed against an indigenous protein, thus circumventing the need for genetic modifications of the target cells. We had hoped that the Psi1 reporter could be used to study broader populations of pseudomonads, but the narrow specificity of the antibody precluded this approach. Therefore, we are currently planning experiments to investigate phosphate availability for selected strains introduced into the soil environment.

\section{ACKNOWLEDGEMENTS}

This work was supported by the Danish Center for Microbial Ecology, the Hofmans Gave Foundation and the Danish Veterinary and Agricultural Research Council (grant no. 9313839). We gratefully acknowledge the technical assistance of Lene M. Nielsen. Anne Blicher and Bente Isbye are thanked for performing the amino acid composition and the amino acid sequence analysis, respectively, and Michael Hansen for assistance during photographic reproduction of immunofluorescence preparations.

\section{REFERENCES}

Barkholt, V. \& Jensen, A. L. (1989). Amino acid analysis: determination of cystein plus half cystine in proteins after hydrochloric acid hydrolysis with a disulphide compound as additive. Anal Biochem 177, 318-322.

Barrett, E. L., Solanes, R. E., Tang, J. S. \& Palleroni, N. J. (1986). Pseudomonas fluorescens biovar $\mathrm{V}$ : its resolution into distinct component groups and the relationship of these groups to other $P$. fluorescens biovars, to $P$. putida, and to psychrotrophic pseudomonads associated with food spoilage. J Gen Microbiol 132, 2709-2721.

Blum, H., Beier, H. \& Gross, H. J. (1987). Improved silver staining of plant proteins, RNA and DNA in polyacrylamide gels. Electrophoresis 8, 93-99.

Boye, M., Ahl, T. \& Molin, S. (1995). Application of a strainspecific rRNA oligonucleotide probe targeting Pseudomonas fluorescens $\mathrm{Ag} 1$ in a mesocosm study of bacterial release into the environment. Appl Environ Microbiol 61, 1384-1390.

Cebolla, Á., Gusmán, C. \& de Lorenzo, V. (1996). Nondisruptive detection of activity of catabolic promoters of Pseudomonas putida with an antigenic surface reporter system. Appl Environ Microbiol 62, 214-220.

De Mot, R., Schoofs, G., Roelandt, A., Declerck, P., Proost, P., van Damme, J. \& Vanderleyden, J. (1994). Molecular characterization of the major outer membrane protein OprF from plant root colonizing Pseudomonas fluorescens. Microbiology 140, 1377-1387.

De Weger, L. A., Dekkers, L. C., van der Bij, A. J. \& Lugtenberg, B. J. J. (1994). Use of phosphate-reporter bacteria to study phosphate limitation in the rhizosphere and in bulk soil. Mol Plant-Microbe Interact 7, 32-38.

Duchêne, M., Schweizer, T., Lottspeich, F., Krauss, G., Marget, M., Vogel, K., von Specht, B.-U. \& Domdey, H. (1988). Sequence and transcriptional start site of the Pseudomonas aeruginosa outer membrane porin protein F gene. J Bacteriol 170, 155-162.

Eberl, L., Givskov, M., Sternberg, C., Møller, S., Christiansen, G. \& Molin, S. (1996). Physiological responses of Pseudomonas putida KT2442 to phosphate starvation. Microbiology 142, 155-163.

Filip, C., Fletcher, G., Wulff, J. L. \& Earhart, C. F. (1973). Solubilization of the cytoplasmic membrane of Escherichia coli by the ionic detergent sodium-lauryl sarcosinate. J Bacteriol 115, 717-722.

Givskov, M., Eberl, L. \& Molin, S. (1994). Responses to nutrient starvation in Pseudomonas putida strain KT2442: two-dimensional electrophoretic analysis of starvation and stress inducible proteins. J Bacteriol 176, 4816-4824.

Hancock, R. E. W. \& Benz, R. (1986). Demonstration and chemical modification of a specific phosphate binding site in the phosphatestarvation-inducible outer membrane porin protein $\mathrm{P}$ of Pseudomonas aeruginosa. Biochim Biophys Acta 860, 699-707.

Hancock, R. E. W., Poole, K. \& Benz, R. (1982). Outer membrane protein $\mathrm{P}$ of Pseudomonas aeruginosa: regulation by phosphate deficiency and formation of small anion-specific channels in lipid bilayer membranes. J Bacteriol 150, 730-738.

Hancock, R. E. W., Siehnel, R. \& Martin, N. (1990). Outer membrane proteins of Pseudomonas. Mol Microbiol 4, 1069-1075.

Hancock, R. E. W., Egli, C., Benz, R. \& Siehnel, R. J. (1992). Overexpression in Escherichia coli and functional analysis of a novel $\mathrm{PP}_{\mathrm{i}}$-selective porin, OprO, from Pseudomonas aeruginosa. J Bacteriol 174, 471-476.

Harry, E. J., Pogliano, K. \& Losick, R. (1995). Use of immunofluorescence to visualize cell-specific gene expression during sporulation in Bacillus subtilis. J Bacteriol 177, 3386-3393.

Heinonen, J. K. \& Lahti, R. J. (1981). A new convenient colometric 
determination of inorganic orthophosphate and its application to the assay of inorganic pyrophosphate. Anal Biochem 113, 313-317.

Höfte, M., Boelens, J. \& Verstraete, W. (1991). Seed protection and promoting of seedlings by plant growth beneficial Pseudomonas strains 7NSK2 and ANP15. Soil Biol Biochem 23, 407-410.

Jeanteur, D., Lakey, J. H. \& Pattus, F. (1991). The bacterial porin superfamily: sequence alignment and structure prediction. $\mathrm{Mol}$ Microbiol 5, 2153-2164.

Judd, R. C. (1988). Purification of outer membrane proteins of the Gram-negative bacterium Neisseria gonorrhoeae. Anal Biochem 173, 307-316.

Jungk, A., Seeling, B. \& Gerke, J. (1993). Mobilization of different phosphate fractions in the rhizosphere. Plant Soil 155/156, 91-94.

Keel, C., Wirthner, P. H., Oberhansli, T. H., Voisard, C., Burger, Haas, D. \& Defago, G. (1990). Pseudomonads as antagonists of plant pathogens in the rhizosphere: role of antibiotic 2,4diacetylphloroglucinol in the suppression of black root of tobacco. Symbiosis 9, 327-341.

Kragelund, L. \& Nybroe, O. (1994). Culturability and expression of outer membrane proteins during carbon, nitrogen or phosphorus starvation of Pseudomonas fluorescens DF57 and P. putida DF14. Appl Environ Microbiol 60, 2944-2948.

Kragelund, L. \& Nybroe, O. (1995). Distribution and starvation response of lux-tagged Pseudomonas fuorescens reporter bacteria in the barley rhizosphere. In 7th International Symposium on Microbial Ecology, abstracts, p. 137. São Paulo: Brazilian Society for Microbiology.

Kragelund, L., Christoffersen, B., Nybroe, O. \& de Bruijn, F. J. (1995). Isolation of lux reporter gene fusions in Pseudomonas fluorescens DF57 inducible by nitrogen or phosphorus starvation. FEMS Microbiol Ecol 17, 95-106.

Kragelund, L., Leopold, K. \& Nybroe, O. (1996). Outer membrane protein heterogeneity with Pseudomonas fluorescens and Pseudomonas putida and use of an OprF antibody as a probe for rRNA homology group I pseudomonads. Appl Environ Microbiol 62, $480-485$.

van der Ley, P., Kuipers, O., Tommassen, J. \& Lugtenberg, B. (1986). O-antigenic chains of lipopolysaccharide prevent binding of antibody molecules to an outer membrane pore protein in Enterobacteriaceae. Microb Pathog 1, 43-49.

Maddock, J. R. \& Shapiro, L. (1993). Polar location of the chemoreceptor complex in the Escherichia coli cell. Science 259, 1717-1723.

Matsudaira, P. (1987). Sequence from picomole quantities of protein electroblotted onto polyvinylidene fluoride membrane. J Biol Chem 262, 10035-10038.

Mazzola, M. \& Cook, R. J. (1991). Effects of fungal root pathogens on the population dynamics of biocontrol strains of fluorescent pseudomonads in the wheat rhizosphere. Appl Environ Microbiol 57, 2171-2178.

Mizuno, T. \& Kageyama, M. (1979). Isolation and characterization of major outer membrane proteins of Pseudomonas aeruginosa strain PAO with special reference to peptidoglycan-associated protein. J Biochem 86, 979-989.

Olsen, P. E. \& Rice, W. A. (1989). Rhizobium strain identification and quantification in commercial inoculants by immunoblot analysis. Appl Environ Microbiol 55, 520-522.

Overbeeke, N., Bergmans, H., van Mansfield, F. \& Lugtenberg, B. (1983). Complete nucleotide sequence of $p h o E$, the structural gene for the phosphate limitation inducible outer membrane pore protein of Escherichia coli K12. J Mol Biol 163, 513-532.

Poole, K. \& Hancock, R. E. W. (1986). Phosphate-starvation induced outer membrane proteins of members of the families Enterobacteriaceae and Pseudomonadaceae: demonstration of immunological cross-reactivity with antiserum specific for protein P of Pseudomonas aeruginosa. J Bacteriol 156, 987-993.

Poole, K., Parr, T. R., Jr \& Hancock, R. E. W. (1987). Phosphateselective porins from the outer membrane of fluorescent Pseudomonas sp. Can J Microbiol 33, 63-69.

Ramos, J. E., Diaz, E., Cowling, D., de Lorenzo, V., Molin, S., O'Gara, F., Ramos, C. \& Timmis, K. (1994). The behaviour of bacteria designed for biodegradation. Bio/Technology 12, 1349-1358.

Rawling, E. G., Martin, N. L. \& Hancock, R. E. W. (1995). Epitope mapping of the Pseudomonas aeruginosa porin protein OprF. Infect Immun 63, 38-42.

Schaule, G., Flemming, H.-C. \& Ridgway, H.-F. (1993). Use of 5cyano-2,3-ditolyl tetrazolium chloride for quantifying planktonic and sessile respiring bacteria in drinking water. Appl Environ Microbiol 59, 3850-3857.

Siehnel, R. J., Martin, N. L. \& Hancock, R. E. W. (1990). Sequence and relatedness in other bacteria of the Pseudomonas aeruginosa OprP gene coding for the phosphate-specific porin P. Mol Microbiol 4, 831-838.

Siehnel, R. J., Egli, C. \& Hancock, R. E. W. (1992). Polyphosphateselective porin OprO of Pseudomonas aeruginosa: expression, purification and sequence. Mol Microbiol 6, 2319-2326.

Sørensen, J., Skouv, J., Jørgensen, A. \& Nybroe, O. (1992). Rapid identification of environmental isolates of Pseudomonas aeruginosa, P. fluorescens and P. putida by SDS-PAGE analysis of whole-cell protein patterns. FEMS Microbiol Ecol 101, 41-50.

Tsai, C.-M. \& Frasch, C. E. (1982). A sensitive silver stain for detecting lipopolysaccharide in polyacrylamide gels. Anal Biochem 119, 115-119.

Worobec, E. A., Martin, N. L., McCubbin, W. D., Kay, C. M. Brayer, G. D. \& Hancock, R. E. W. (1988). Large-scale purification and biochemical characterization of crystallization-grade protein P from Pseudomonas aeruginosa. Biochim Biophys Acta 939, 366-374.

Yamamoto, K., Uozumi, T. \& Beppu, T. (1987). The blue copper protein gene of Alcaligenes faecalis S-6 directs secretion of blue copper protein from Escherichia coli cells. J Bacteriol 169, 5648-5652.

Zaat, S. A. J., Slegtenhorst-Eegdeman, K., Tommassen, J., Geli, V., Wijffelman, C. A. \& Lugtenberg, B. J. J. (1994). Construction of phoE-caa, a novel PCR- and immunologically detectable marker gene for Pseudomonas putida. Appl Environ Microbiol 60, 3965-3973.

Received 19 September 1996; revised 21 October 1996; accepted 23 October 1996. 